\title{
Scaffolding the Success of the Youth through Education
}

\author{
Aris Reynold V. Cajigal and Jeanette G. Dials
}

\begin{abstract}
Intelligent, witty, enthusiastic, are three words that generally describe the young people of Ilocos Norte. This paper presented the various education-related programs of the Provincial Government of Ilocos Norte, Philippines. It specifically aimed to discuss the initiatives of the government in meeting the targets under the Millennium Development Goals (MDG) and in helping Filipino students achieve their educational aspirations. The 2012 survey revealed that the province's enrolment rates of children aged 6-12 and 13-16 are $\mathbf{8 5 . 3 \%}$ and $\mathbf{7 6 . 5 \%}$, respectively. These data showed a gap between the actual rate and the ideal $100 \%$ participation rate as expected in the MDG on primary education. Challenged by the existence of this gap and driven by the desire to improve the performance of Ilocos Norte along this MDG target, the government has taken steps to ensure universal education for the Ilocano youth. These initiatives include a comprehensive scholarship program in the elementary, high school, and college levels, extensive school improvement, teacher empowerment, and subsidy for basic school resources and utilities, and transportation subsidies. It used the descriptive research design with the purpose of elaborating the details of the various projects in education.
\end{abstract}

Index Terms-Education initiative, instructional scaffolding, school programs, quality education.

\section{INTRODUCTION}

Every child has a dream. For the Ilocano, his/her dream is to have a bright and successful future. Parents and their children work together harmoniously to achieve their goals in life. It has been noted that Ilocano families value education. They spend all their money and exhaust all their means just to get quality education. Ilocanos believe in the power of education in emancipating them from the bondage of ignorance and poverty. They regard learning and education as prerequisite, basis and focal point of development. However, challenges beset every family. These challenges consequently cause the disruption of the schooling of children. In the remote areas of the province, school children tend to miss school because of financial difficulties, distance of the school from their homes, and the pressure to work for the family and help in meeting the basic needs of the family. Schools cannot sustain the ideal student-teacher ratio because of the lack of teachers. Much worse, the teachers hold their classes outdoors due to lack of classrooms or dilapidated rooms.

Scaffolding is a term used in architecture and engineering. In an academic sense, a scaffold helps learners acquire skills that they would unlikely to acquire without assistance [1]. The

Manuscript received February 20, 2016; revised July 13, 2016

Aris Reynold V. Cajigal is with the Mariano Marcos State University, Philippines. He is also with the University of Georgia, USA (e-mail: arvcajigal@yahoo.com).

Jeanette G. Dials is with the Mariano Marcos State University, Philippines (e-mail: jd_0256@yahoo.com). scaffolding helps minimize the extrinsic load so that learners can focus their resources on the intrinsic demands of the learning. It must be noted that as the learners develop a schema to work with the given information, the scaffold assistance can be removed. In like manner as the scaffold in the learning context, children and students need scaffolds in different ways to sustain their interest and growth in finishing their schooling. In this paper, the scaffolds come from the government. These scaffolds are in the form of material and non-material assistance to schools, parents, teachers, and children.

The stark realities in the province's education system have urged the Provincial Government of Ilocos Norte (PGIN) to embark on education initiatives to address the needs of children and students in education. Through the leadership of Governor Imee R. Marcos, several projects have been conceptualized and implemented to help poor children and boost their spirit of achieving their dreams. The government has designed initiatives in meeting the targets under the Millennium Development Goals (MDG) and in helping Ilocano students achieve their educational aspirations. The 2012 survey revealed that the province's enrolment rates of children aged 6-12 and $13-16$ are $85.3 \%$ and $76.5 \%$, respectively [2]. In the elementary level, there is an increase in the participation rate, from $93.11 \%$ in $2010-2011$ to $95.59 \%$ in 2011-2012. In the high school level, there is a decrease in the participation rate, from $72.44 \%$ in $2010-2011$ to $71.15 \%$ in $2011-2012$. These data showed a gap between the actual rate and the ideal $100 \%$ participation rate as expected in the MDG on primary education. Challenged by the existence of this gap and driven by the desire to improve the performance of Ilocos Norte along this MDG target, the provincial government has taken steps to ensure universal education for the Ilocano youth. This paper was conceptualized to elaborate the various projects of the provincial government. The researchers who are deeply involved in the said projects felt the need to document and pursue a study to explain, discuss, and open the gates to an understanding of the role played by the government in meeting the needs of school children.

\section{OBJECTIVES OF THE STUDY}

This study aims to describe the various government projects of the Provincial Government of Ilocos Norte in the field of education. More specifically, it attempts to:

1) make a detailed description of the various education programs of the provincial government;

2) discuss the benefits of the programs to different stakeholders; and

3) elaborate the concerns and challenges encountered in the implementation; 


\section{REVIEW OF LITERATURE}

Horace Mann's popular maxim, "Education is the great equalizer" holds true in the lives of the people of Ilocos Norte. Ilocanos value education as it is believed to be the means for upward social mobility. Education provides opportunity to grow financially, alleviate poverty, empower people, and cherish a democratic way of life. Most of the school-aged children finish basic education (K-10) while others leave school without finishing their education. It is a known scenario that students who drop out of school are those who are faced with financial challenges.

Dropping out from school is a global problem. The problem of developing countries shifted from getting children into school to keeping them in school [2]. They further posit that children who leave school before they have finished the curriculum do not develop their potentials to the fullest and results to a government wasting its limited resources. Family income may not be enough to augment their schooling so children drop out. Likewise, students may opt to help their families in seeking for employment. Even in other contexts, socioeconomic status has been related to academic success of school-aged children. Some of these places are wrought with financial difficulties, neglect by the local government, natural disasters, and armed conflicts.

Socioeconomic status (SES), usually indicated by educational attainment, resources, and wealth, has been known to influence the success of students. The lack of or limited family resources often affect the schooling of children, especially those who are living in depressed and impoverished areas. Low socioeconomic status has deleterious effects on the well-being and development of children and adolescents [3] Furthermore they claimed that SES has significant effects on literacy and language, aggression, and depression. Likewise, Sirin, through a meta-analysis of the literature found that there is a medium to strong SES-achievement relation [4]. It was even reported that socioeconomic and demographic characteristics influence the decision of school children to drop out from school [5]. In particular, parental education and family wealth influences dropping out from schools. The other factors influencing dropping out from school include number of siblings in the family, parental guidance, duration of primary education, chances of finding a job, and quality of educational facilities. In a more subject-specific study, [6] it concluded that family SES, school programmatic factors, and some other school resource and institutional factors are significantly related to math and science achievement across all countries. In another study [7] it argued that by and large, students with higher socioeconomic status are those who have access to the best resources in their education. Other relevant studies found that socioeconomic status has an impact on academic outcomes [8], level of math and reading achievement [9], literacy achievement in all English-speaking countries [10], and help-seeking strategies of children [11].

The effect of socioeconomic status on the academic success of children is a well-studied area. One of the most popular results of these studies was reported that socioeconomic status and learning relationship varies cross-nationally [12]. The phenomenon was later known as the Heyneman-Loxley effect.
These researchers demonstrated that the influence of socioeconomic status varies significantly depending on national economic development. To them, family socioeconomic status matters more than schools for student learning outcomes in industrialized countries, while schools exert a greater influence on student learning in less-developed nations. It means that countries with lower levels of development are those with weaker effects of families on the educational outcomes of students. On the other hand, the stronger impact of school quality on achievement of students in developing countries was attributed to the larger variation in school resources and quality found in those countries. However, many refuted that there was no longer a strong impact of school quality on achievement in developing countries [13]. This was due to an apparent weakening of the effects of schools on educational outcomes to increasing commitment to universal education. Both studies show that the influence of socioeconomic status varies cross-nationally and institutions have the ability to change the conditions by which families and schools influence achievement [14]. In the Philippines, it was found that the Heyneman-Loxley effect does not exist as shown by his findings from his research sample [15]. However, he contends that schools are important in the production of higher achievement scores.

The Provincial Government of Albay, under the administration of Governor Joey Salceda, has spearheaded various education-related projects. These inspired other local government units to also invest in the education sector. In his presentation, he elaborated his goal of increasing the participation of Albayanos in education. In particular, he explained the two important educational projects the Provincial Government of Albay is pursuing-the EQUAL (Education Quality for Albayanos) and AHECS (Albay Higher Education Contribution Scheme) Projects. The projects are anchored on the need to shift from physical capital formation to human capital formation and the desire of having "a college graduate in every family". EQUAL aims to provide universal access to education, enhance the quality of education, and promote continuing education and development. It started with $\mathrm{Php} 40$ million-subsidy with 7,183 scholars in 2010 and now increased to about 34, 000 scholars in 2013. AHECS was launched as a concession loan facility designed for students of Albay in their pursuit of higher education. It is funded by a Php 16-million subsidy [16].

The Provincial Government of Ilocos Norte, through the able leadership of Governor Imee R. Marcos has embarked on a noble mission of empowering the Ilocano youth by supporting their journey in the educational ladder. It is the ultimate goal of the provincial government to help the financially challenged but performing Ilocano students in their quest for knowledge. It is within this context and premise that the researchers were motivated to pursue a descriptive study to highlight the 'scaffolding' initiatives of the Provincial Government of Ilocos Norte. In the end, the academic success Ilocano youth would be the ultimate goal and be given paramount importance.

The concept of instructional scaffolding comes from the works of Wood, Bruner and Ross. The term was used as a 
metaphor to describe the type of assistance offered by a teacher or peer to support learning [17]. In this process, the teacher helps the student master a task he/she is initially unable to grasp independently. They add that the teacher only attempts to help the student with tasks that are just beyond his/her current capability. In scaffolding, "fading" (gradual removal of the scaffolding) occurs when the student takes the responsibility for or masters the given task. In this paper, the term scaffolding was used to denote the government's assistance given to school-age children in order to finish their education [18]. Using the same analogy of scaffolding in teaching and learning, the Provincial Government of Ilocos Norte has designed the 'scaffolds' to help Ilocano students achieve their educational aspirations. These scaffolds, in effect, serve as a bridge to build upon what the students already have.

\section{Methodology}

The methodology of a study elaborates the plan of action, process, or design that informs the methods chosen [19]. A plan of action is necessary to attain the goal of answering the questions raised by a researcher.

This study made use of the descriptive research design with the purpose of elaborating the details of the various projects in education. Descriptive research is a purposive process of gathering, analyzing, classifying, and tabulating data about conditions of relationship that exist; practices that prevail; beliefs and processes; or trends that are developing [20].

The study employed different research methods. These multiple methods included interviews, focus group discussion, and collection of necessary documents from the concerned government offices. Multiple data sources were used to enhance research viability [21]. Triangulation, or the use of multiple sources of data is also used as it enhances a study by bringing together more than one source of evidence to corroborate, elaborate, or illuminate a research question under investigation [22]. Triangulation as a strategy provides evidence for the researcher to make sense of some social phenomenon, but that the triangulation strategy does not, in and of itself, do this [23]. The possible outcomes of triangulation may include: (1) Convergence when a single proposition about the social phenomenon being studied results from analysis; (2) Inconsistency when the range of data sources and methods do not confirm a single proposition about the phenomenon; and (3) Contradiction when contradictory and opposing views of the social phenomenon result. The use of multiple sources of evidence allows the development of converging lines of inquiry to address historical, attitudinal, and behavioral issues [24].

Semi-structured interviews were used to explore the benefits, concerns and challenges encountered by the beneficiaries and to uncover the beliefs, attitudes, and experiences during the implementation of the various programs. Interviewing allows researchers to understand the world from the participants' viewpoint and to unfold the meaning of their experiences [25].

It was very important to secure the needed documents for analysis. This process was necessary to have a basis in coming up with valid generalizations. These documents included reports of attendance, list of scholars, budgets, payrolls, legal documents, to name a few.

The researchers employed an inductive analysis of the data obtained in this study [26]. In particular, data were coded and organized into themes to capture the real picture of the phenomenon under investigation.

The present study is limited to the five major education-related projects of the Provincial Government of Ilocos Norte. There are other projects not within the scope of this study. These five projects were chosen on the basis of the following factors: (a) time/duration of the conceptualization and implementation phases of the project; (b) direct/indirect impact to the education of Ilocano students (elementary, high school, and college levels); (c) province-wide scope of the project; and (d) availability of official documents.

\section{FINDINGS}

The following projects are being implemented by the Provincial Government of Ilocos Norte, under the leadership of Governor Imee R. Marcos:

\section{A. Scholarship Program}

Dubbed as Iskolar ni Manang Imee program, thousands of elementary, high school, and college students enjoy scholarship grants. Elementary pupils receive Php 250 to help them pay their school fees. High school students receive Php 450 for the same purpose. In the college level, scholars enrolled in the priority degree programs enjoy free tuition and fees. They also receive a monthly stipend amounting to Php 2250 to support their schooling (stipend, transportation and lodging allowance). The Iskolar ni Manang Imee, which has a total of 232 scholars in the tertiary level, all enrolled in the Mariano Marcos State University was allotted the amount of Php 7,261,600.00 for the year 2012 .

TABLE I: DISTRIBUTION OF IMEE SCHOLARS (COLLEGE)

\begin{tabular}{|c|c|c|c|}
\hline College & & \multicolumn{2}{|c|}{ Number of Scholars } \\
\hline & $\mathbf{2 0 1 1}$ & $\mathbf{2 0 1 2}$ & $\mathbf{2 0 1 3}$ \\
\hline CAS & 14 & 20 & 8 \\
\hline CBEA & 52 & 120 & 76 \\
\hline CHS & 1 & 5 & 6 \\
\hline CAFSD & 1 & 8 & 10 \\
\hline CASAT & 9 & 8 & 4 \\
\hline CIT & -- & 4 & 8 \\
\hline COE & -- & 14 & 22 \\
\hline CTE & 27 & 53 & 36 \\
\hline Total & & 232 & 170 \\
\hline
\end{tabular}

Recognizing that the main reason for drop outs or long absences of pupils and students is due to the limited financial resources of the family to pay for contributions, the PGIN under the Education Department assisted pupils and students identified as indigents by the PSWDO based on the records of National Housing Targeting System (NHTS). These records were then verified and evaluated by the DepEd and submitted to Provincial Education Department (PED), which then endorsed the list to the Office of the Governor for approval. The approved list was the basis for the grant of the financial assistance.

In coordination with the Local Finance Committee, the 
amount of Php 450.00 for each high school student and Php 250.00 for each elementary pupil were distributed on different dates to the various schools in the different municipalities in Ilocos Norte. Such amounts were based on the actual expenses indicated in their school fees. With the grant of this financial assistance it was noted that there was an increase in the Retention and Participation rates. There was also a decrease of $0.70 \%$ in the drop-out rate.

The Education Department targeted twelve thousand $(12,000)$ pupils and four thousand five hundred $(4,500)$ high school students. The turn-out of enrolment was 13,948 and 6,053 for elementary and high school students, respectively. There was an increase of $16 \%$ for the elementary pupils and $34 \%$ for the high school students.

TABLE II: DISTRIBUTION OF IMEE SCHOLARS (ELEMENTARY AND HIGH SCHOOL LEVELS)

\begin{tabular}{|c|c|c|c|c|}
\hline Level & Number of Schools & \multicolumn{2}{c|}{ Number of Recipients } \\
\hline & $\mathbf{2 0 1 1}$ & $\mathbf{2 0 1 2}$ & $\mathbf{2 0 1 1}$ & $\mathbf{2 0 1 2}$ \\
\hline Elementary & 200 & 345 & 6,939 & 22,161 \\
\hline High School & 44 & 60 & 2,181 & 9,465 \\
\hline TOTAL & 244 & 405 & 9,120 & 31,626 \\
\hline
\end{tabular}

TABLE III: AMOUNT SPENT FOR THE SCHOLARSHIP PROGRAM

\begin{tabular}{|c|c|c|c|}
\hline \multirow{2}{*}{ Level } & & & \\
\cline { 2 - 4 } & 2011 & 2012 & Total \\
\hline College & $1,611,950$ & $8,795,300$ & $10,407,250$ \\
\hline High School & 981,450 & $4,259,250$ & $4,260,231$ \\
\hline Elementary & $1,734,750$ & $5,540,250$ & $7,275,000$ \\
\hline TOTAL & $4,328,150$ & $18,594,800$ & $21,942,481$ \\
\hline
\end{tabular}

\section{B. School Repair}

Every start of the school year, selected schools are given materials for urgent repair. These identified schools are visited by the Engineering Department to assess the damage. School buildings with the most severe damage are given priority. Interestingly, once the materials are delivered to the school beneficiaries, all community people help in the repair of the damaged portion of the building. Bayanihan spirit is still evident.

This program aims to provide a more conducive teaching-learning environment for the pupils/students and teachers. Repair, maintenance and improvement of old dilapidated school buildings were undertaken to rehabilitate damaged school buildings and facilities.

TABLE IV: AMOUNT SPENT FOR SCHOOL REPAIR/IMPROVEMENT

\begin{tabular}{|c|c|c|}
\hline Year & No. of Schools & Total Amount \\
\hline 2011 & 28 & $4,306,680.43$ \\
\hline 2012 & 61 & $8,548,030.76$ \\
\hline 2013 & 40 & $2,568,774.96$ \\
\hline TOTAL & 129 & $15,423,486.15$ \\
\hline
\end{tabular}

\section{Subsidy for Electric Bills (Elementary Level)}

The "Kuryente Mo, Sagot Ko Project of the Provincial Government aims to subsidize the payment for electrical consumption of the 200 identified MDG Schools to ease the burden of school heads and parents in paying the bills. The basis in the computation of the baseline for the payment of the consumption shall be the average consumption of the schools in the last two years. However, the school should not exceed the computed average charge. If at one point, the school will exceed, it is the responsibility of the school concerned to pay the excess. The amount to be paid by the province will depend on whichever is lower between the average monthly bill and the current bill. This program is funded under the Special Education Fund of the Province, Subsidy for the Payment of Utilities of MDG Schools/Division Office.

TABLE V: NUMBER OF SCHOOL RECIPIENTS AND AMOUNT SPENT FOR ELECTRIC BILLS

\begin{tabular}{|c|c|c|}
\hline Year & No. of Schools & Total Amount \\
\hline 2011 & 200 & $1,200,060.00$ \\
\hline 2012 & 187 & $1,604,386.19$ \\
\hline 2013 & 237 & $229,233.86$ \\
\hline TOTAL & & $3,033,680.05$ \\
\hline
\end{tabular}

\section{Provision for School Transportation}

The Siribus and Sirib E-Jeepneys given to selected municipalities and cities in the province provide easy transportation to commuting students. It is the Ilocano version of the American school bus, the transportation used to ferry students to and from the school.

TABLE VI: NUMBER OF VEHICLES PROVIDED FOR STUDENTS

\begin{tabular}{|c|c|c|}
\hline Year & Number of Siribus & $\begin{array}{c}\text { Number of Sirib } \\
\text { E-Jeepneys }\end{array}$ \\
\hline 2011 & $\begin{array}{c}2 \text { (service for 20 } \\
\text { schools in Laoag City } \\
\text { and Badoc) }\end{array}$ & $\begin{array}{c}\text { 1 (service for 10 } \\
\text { schools in Laoag } \\
\text { City) }\end{array}$ \\
\hline 2012 & $\begin{array}{c}2 \text { (service for 20 } \\
\text { schools in Bacarra and } \\
\text { Piddig) }\end{array}$ & $\begin{array}{c}1 \text { (service for 7 } \\
\text { schools in Paoay) }\end{array}$ \\
\hline 2013 & $\begin{array}{c}3 \text { (service for 22 } \\
\text { schools in Sarrat, } \\
\text { Bangui and Pasuquin) }\end{array}$ & -- \\
\hline TOTAL & 7 & 2 \\
\hline
\end{tabular}

\section{E. Subsidy for Teachers of Temporary Positions}

Provincial Ordinance No. 041-2011 otherwise known as the "Ordinance Institutionalizing the "Saguip Maestra Program of the Province of Ilocos Norte, Providing Funds Therefor and for other Purposes.", is an educational assistance program that is one big step forward towards attaining accessible quality education for the people.

This program provides: a) accessible quality education to the people through an educational assistance by contracting, as far as practicable, additional qualified teachers to be assigned to the different elementary and secondary schools in the province; b) provide employment to competent and deserving professional teachers to render their needed services and to augment the insufficient and inadequate regular teaching personnel of the school to meet the increasing demand of a growing student populace in the province through the employment of additional teachers under this program.

Originally there were fifty (50) contractual teachers who were deployed to the different schools within the province. Salaries and other benefits of these teachers were funded from the PAGCOR funds. However, for the year 2012, there were only thirty-nine (39) teachers left with the Saguip Maestra Program since the other teachers were directly hired by the schools. Twenty-three (23) different elementary and high schools benefitted from this Program.

In 2012, sixteen teachers were deployed to five - first and second class LGUs under the 50/50 percent sharing scheme 
between the provincial government and the LGUs while the twenty-three (23) teachers were assigned to the $6-3^{\text {rd }}$ and $4^{\text {th }}$ class LGU whose salary were $100 \%$ subsidized by the provincial government. A total of One Million Eight Hundred Sixty Pesos $(1,860,000.00)$ was spent for this program.

TABLE VII: NUMBER OF SAGIP MAESTRA BENEFICIARIES AND AMOUNT SPENT

\begin{tabular}{|c|c|c|c|}
\hline Year & $\begin{array}{c}\text { Number of } \\
\text { Schools }\end{array}$ & $\begin{array}{c}\text { Number of } \\
\text { Teachers }\end{array}$ & Amount \\
\hline 2011 & 35 & 69 & $2,910,000.00$ \\
\hline 2012 & 23 & 50 & $1,860,000.00$ \\
\hline 2013 & 4 & 13 & $312,000.00$ \\
\hline TOTAL & 62 & 132 & $5,082,000.00$ \\
\hline
\end{tabular}

Concerns and challenges in the project implementation.

1) Difficulty in the validation of pupil/student recipients due to limited and inconsistent database of DSWD.

2) Limited funding to increase and sustain teaching positions under the Sagip Maestra Program.

3) Concerns with the mechanism of payment of electric bills (with INEC)

4) Limited funding to accommodate all requests for school repair. A mechanism was designed to prioritize schools according to the assessment of the Provincial Engineering Office.

5) The teachers are appealing that the cash ( $P 250$ for elementary; P 450 for high school) usually given to the students/parents for the payment miscellaneous fees be given directly to the teachers. There were cases when the money was not used to pay the required school fees thereby resulting to problems among teachers. There were even cases when parents refuse to pay the fees and instead spend the money for other things.

6) The cost of transportation and food during the MDG Distribution in the different municipalities is higher than the amount ( $\mathrm{P} 250$ or $\mathrm{P} 450$ ) to be received by the students. It is requested that transportation be provided to students from remote schools during distribution. Alternatively, it is requested that staff from the Provincial Government just distribute the stipends to the schools in remote communities.

\section{RECOMMENDATIONS}

It was found in this study that there are various projects of the Provincial Government in the education sector. It is concluded that these projects were beneficial to the intended clientele. It helped them in many ways and resulted in the decrease of the cost of schooling for the children of school age. Lastly, the beneficiaries and implementing agencies encountered some challenges that needed immediate attention. These include problems in coordination with local officials, validity of list of beneficiaries, distance, funding sources, and manpower resources. These are continuously remedied when encountered.

\section{FUTURE DIRECTIONS}

The researchers intend to continue examining other aspects of the educational programs of the Provincial Government of
Ilocos Norte. More specifically, the following areas will be considered:

1) Case studies on specific projects.

2) Results of formative and summative evaluation of each project

3) Impact studies

4) Narrative analysis of interviews with students and parents

5) Longitudinal study on the employability of IMEE scholars

6) Descriptive study on recently launched projects in education (S-Mile, Campus express, Capitol express, iHubs, etc.)

\section{REFERENCES}

[1] D. Schunk, Learning theories: An educational Perspective ( $5^{\text {th }}$ ed.), Upper Saddle, NJ: Pearson Prentice Hall, 2008.

[2] J. Huisman and J. Smits, "Keeping children in school: Household and district-level determinants of school dropout in 363 districts of 30 developing countries," 2009.

[3] N. L. Letourneau, L. Duffett-Leger, I. L. Levac, B. Watson, and C. Young-Morris, "Socioeconomic status and child development: A meta-analysis," Journal of Emotional and Behavioral Disorders, vol. 21, no. 3, pp. 211-224, 2013.

[4] S. R. Sirin, "Socioeconomic status and academic achievement: A meta-analytic review of research," Review of Educational Research, vol. 75, no. 3, pp. 417-453, 2005.

[5] J. Huisman and J. Smits, "Keeping children in school: Household and district-level determinants of school dropout in 363 districts of 30 developing countries," 2009.

[6] S. Sousa and D. J. Armor, "Impact of family versus school factors on cross-national disparities in academic achievement: Evidence from the 2006 PISA survey," George Mason University, 2010.

[7] S. M. Arnett, "National variation in the effects of socioeconomic status on student learning: Inequality and stratification in comparative perspective," Doctoral dissertation, University of Notre Dame, Indiana, 2007.

[8] E. Porfeli, C. Wang et al., "Influence of social and community capital on student achievement in a large urban school district," Education and Urban Society, vol. 42, pp. 72-95, 2009.

[9] E. J. Dixon-Roman, "The forms of capital and the developed achievement of Black males," Urban Education, vol. 48, pp. 828-862, 2013.

[10] J. Buckingham et al., "Why poor children are more likely to become poor readers: The school years," Australian Journal of Education, Advance Online Publication, 2013.

[11] J. M. Calarcoa, “'I need help!' Social class and children's help-seeking in elementary school," American Sociological Review, vol. 76, pp. 862-882, 2011.

[12] S. P. Heyneman and W. A. Loxley, "The effect of primary-school quality on academic achievement across high-income and low-income countries," American Journal of Sociology, vol. 88, pp. 1162-1194, 1983.

[13] D. P. Baker, B. Goesling, and G. K. Tendre, "Socioeconomic status, school quality, and national economic development: A cross-national analysis of the 'Heyneman-Loxley Effect'," Mathematics and Science Achievement, 2002.

[14] S. M. Arnett, "National variation in the effects of socioeconomic status on student learning: Inequality and stratification in comparative perspective," Doctoral dissertation, University of Notre Dame, Indiana, 2007.

[15] F. L. Huang, "The role of socioeconomic status and school quality in the Philippines: Revisiting the Heyneman-Loxley effect," International Journal of Educational Development, vol. 30, pp. 288-296, 2010.

[16] J. Salceda, Education for all-Education for Albayanos, Retrieved March 20, 2013.

[17] D. Wood et al., "The role of tutoring in problem solving," Journal of Psychology and Psychiatry, vol. 17, 1976.

[18] L. Lipscomb et al., "Scaffolding," Emerging Perspectives on Learning, Teaching, and Technology, March 20, 2013.

[19] M. Crotty, The Foundations of Social Research: Meaning and Perspective in the Research Process, Thousand Oaks, CA: Sage Publications, 2003. 
[20] J. F. Calderon and C. Gonzales, Methods of Research and Thesis Writing, Manila: National Bookstore, 2011.

[21] S. R. Sirin, "Socioeconomic status and academic achievement: A meta-analytic review of research," Review of Educational Research, vol. 75 , no. 3, pp. 417-453, 2005.

[22] C. Marshall and G. Rossman, Designing Qualitative Research, $4^{\text {th }}$ Ed., Thousand Oaks, CA: Sage Publications, 2006.

[23] S. Mathison, "Why triangulate?" Educational Researcher, vol. 17, no. 2, pp. 13-17, 1988.

[24] R. K. Yin, Case Study Research: Design and Methods, $2^{\text {nd }}$ Ed., Thousand Oaks, CA: Sage Publications, 1994.

[25] S. Kvale and S. Brinkmann, Interviews: Learning the Craft of Qualitative Research Interviewing, $2^{\text {nd }}$ Ed., Thousand Oaks, CA: Sage Publications, 2009.

[26] K. Charmaz, Constructing Grounded Theory: A Practical Guide through Qualitative Analysis, Thousand Oaks, CA: Sage Publications, 2006.

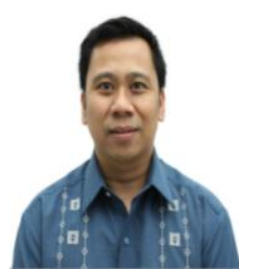

Aris Reynold V. Cajigal was born in Badoc, Ilocos Norte, Philippines on September 22, 1980. He finished the following degrees: the bachelor in secondary education, major in chemistry and the master of arts in Education, major in chemistry from the Mariano Marcos State University (MMSU) in Ilocos Norte, Philippines and Doctor of Philosophy (Ph.D.) in science education from the University of Georgia, Athens, Georgia, USA.

$\mathrm{He}$ is presently serving as director for extension of the Mariano Marcos State University in Ilocos Norte, Philippines. He started as instructor I in 2001 then promoted to Instructor II in 2008, assistant professor II in 2011, associate professor I in 2014 and associate professor $\mathrm{V}$ in 2015. He teaches physical science, educational research, science education, and professional education courses in the undergraduate and graduate levels. His research work focuses on science teaching and learning as well as professional education issues. His involvement in extension activities is along the areas of teacher training, outreach, and technical consultancy.

Dr. Cajigal is an active member of the following professional organizations: Philippine Association of Extension Program Implementors, Inc. (PAEPI), Philippines (2015-present); Nakem Conferences International, Philippine Chapter (2013-present); Philippine Association for the Advancement of Science and Technology (PhilAAST), Philippines (2003-present); Philippine Fulbright Scholars Association, Philippines (2010-present); Pi Lambda Theta International Honor Society and Professional Association in Education, USA (2010-present); National Scholars Honor Society, USA (2008-present); and American Educational Studies Association, USA (2008 - 2009). He was also awarded as Most Outstanding Teacher for 2011 in his university. He finished his $\mathrm{PhD}$ degree in the United States under the Fulbright Scholarship Program.

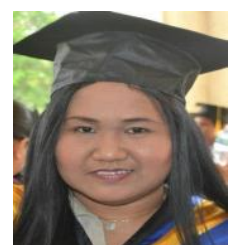

Jeanette G. Dials was born in Quezon city, Philippines on September 13, 1969. She finished her master of arts in education major in English language and literature at the Mariano Marcos State University Graduate School, Laoag City, Philippines in 2006. She has already completed the academic requirements leading to the degree doctor of education major in education management.

She has been teaching English language and literature for 26 years at the College of Teacher Education, Mariano Marcos State University Laoag as an associate professor. She is one of the associate editors of the College of Teacher Education Research Journal and the former department head of the Education Department of the Provincial Government of Ilocos Norte.

Prof. Dials is a member of the Network of Outstanding Teachers of the Philippines (NOTED), International Debate Educators Association, Linguistic Association of the Philippines, College Educator's and Teachers Association (CETA). She is the 2008 Most Outstanding Teacher of the Philippines and the 2009 Most Outstanding School Paper Adviser of the Philippines. 